\title{
Elazığ'da Satılan Hellim Peynirlerinin Mikrobiyolojik ve Kimyasal Kalitesi
}

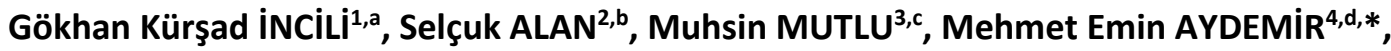 \\ Gülsüm ÖKSÜZTEPE ${ }^{1, e}$
}

\author{
${ }^{1}$ Fırat Üniversitesi, Veteriner Fakültesi, Besin Hijyeni ve Teknolojisi Bölümü, Elazı̆̆, Türkiye \\ ${ }^{2}$ Tarım ve Orman Bakanlığı, Il Tarım ve Orman Müdürlüğü, Elazığ, Türkiye \\ ${ }^{3}$ Tarım ve Orman Bakanlığı, Veteriner Kontrol Enstitüsü, Elazığ, Türkiye \\ ${ }^{4}$ Harran Üniversitesi, Veteriner Fakültesi, Besin Hijyeni ve Teknolojisi Bölümü, Şanlıurfa, Türkiye \\ aORCID:0000-0003-1178-3365, bORCID:0000-0002-4473-7835, cORCID:0000-0003-2097-7217, \\ dORCID: 0000-0002-5849-1741, eORCID: 0000-0003-3267-6841
}

Geliș Tarihi: 04.04.2019

Kabul Tarihi: 21.10.2019

\begin{abstract}
Özet: Bu çalışma Elazığ ilinde satılan hellim peynirlerinin mikrobiyolojik ve kimyasal kalitelerini belirlemek için planlandı. Hellim peyniri örneklerinde mikrobiyolojik (Toplam mezofilik aerob bakteri, Staphylococcus-Micrococcus, LactobacillusLeuconostoc-Pediococcus, laktik streptokoklar, anaerob bakteri, koliform, Enterobacteriaceae, maya ve küf, E. coli, S. aureus), kimyasal (PH, asitlik, kuru madde, tuz, kül, yağ, protein ve su aktivite (aw) değeri) analizler yapıldı. Mikrobiyolojik analizler sonucunda ortalama olarak toplam aerobik mezofilik bakteri sayısı $6.39 \pm 1.88$, Staphylococcus-Micrococcus sayısı $2.63 \pm 1.62$, Lactobacillus-Leuconostoc-Pediococcus sayısı 5.43 \pm 1.73 , laktik streptokok sayısı $6.04 \pm 1.63$, anaerob bakteri sayısı ise $3.45 \pm 1.26 \log _{10} \mathrm{kob} / \mathrm{g}$ olarak tespit edildi. Bakteri sayıları tespit limitinin üzerinde bulunan örneklerde ise Enterobacteriaceae $2.65 \pm 0.9$, koliform grubu bakteri sayı $2.29 \pm 0.73$, maya-küf sayısı $3.16 \pm 1.14$, S. aureus sayısı $2.81 \pm 1.54$ $\log _{10} \mathrm{kob} / \mathrm{g}$ ve olarak tespit edildi. Kimyasal analizler neticesinde ise ortalama olarak kuru madde miktarı \%48.77, kül miktarı \%4.84, tuz miktarı \%6.84, yağ miktarı (kuru maddede) \%41.58, protein miktarı \%30.33, pH değeri 6.58, $a_{w}$ (su aktivite değeri) 0.88 ve asitlik değeri ise (\% laktik asit cinsinden) 0.15 olarak bulundu. Çalışmada incelenen vakum paketli hellim peyniri örneklerinin 30 tanesinin (\%100) kuru madde, 1 tanesinin (\%3.33) tuz miktarı ve 15 tanesinin (\%50) ise pH değerleri bakımından ilgili standarda uymadıkları görüldü. Sonuç olarak, piyasaya çıkarılan ürünlerin hem mikrobiyolojik ve hem de kimyasal diğer parametreler bakımından ilgili standartlara uygun olarak üretilebilmesi için üretimden tüketime kadar olan tüm aşamalarında uygulanan denetimlerin daha sık yapılması soframıza güvenilir ürünlerin gelmesi ve halk sağlığı bakımından büyük önem arz etmektedir.
\end{abstract}

Anahtar kelimeler: Hellim Peyniri, Mikrobiyolojik, Kimyasal, Kalite.

\section{Microbiological and Chemical Quality of Halloumi Cheese Sold in Elazıg}

\begin{abstract}
This study was carried out to determine the microbiological and chemical quality of halloumi cheese sold in Elazığ province. Microbiological (Total mesophilic aerobic bacteria, Staphylococcus-Micrococcus, Lactobacillus-LeuconostocPediococcus, lactic streptococci, anaerobic bacteria, coliform, Enterobacteriaceae, yeast-mold and S. aureus), chemical (PH, acidity value, dry matter, salt, ash, fat, protein and activity of water (aw) ) analyzes were performed in halloumi cheese samples. Microbiological analysis revealed that the mean number of total mesophilic aerobic bacteria, StaphylococcusMicrococcus, Lactobacillus-Leuconostoc-Pediococcus, lactic streptococci, and anaerobic bacteria were 6.39 $\pm 1.88,2.63 \pm 1.62$, $5.43 \pm 1.73,6.04 \pm 1.63$, and $3.45 \pm 1.26 \log _{10} \mathrm{cfu} / \mathrm{g}$, respectively. In the samples with bacteria counts above the detection limit, the mean numbers of Enterobacteriaceae, coliforms, yeast-mold and $S$. aureus were found as 2.65 $\pm 0.9,2.29 \pm 0.73$, $3.16 \pm 1.14$, and $2.81 \pm 1.54 \log _{10} \mathrm{cfu} / \mathrm{g}$, respectively. As a result of chemical anaylsis the mean values of dry matter, total ash, salt, fat (in dry matter), protein, $\mathrm{pH}$, aw value (activity of water) and acidity value (\% lactic acid) were found as $48.77 \%$, $4.84 \%, 6.84 \%, 41.58 \%, 30.33 \%, 6.5,0.88$, and 0.15 , respectively. In the study, 30 samples (100\%) for dry matter, 1 sample (3.33\%) for salt content and 15 samples $(50 \%)$ for $\mathrm{pH}$ values were found to be non-compliant with the related standards. In conclusion, it is important to perform more inspection at all stages from production to consumption to produce foods that are complied with the related standards in terms of the microbiological and chemical parameters as well as for the consumption of healthy and quality food products and protecting the public health.

Keywords: Halloumi Cheese, Microbiological, Chemical Quality.
\end{abstract}

\section{Giriş}

Hellim peyniri, kabuksuz, gözenek içermeyen, sarımsı beyaz renkli, yarı sert veya sert nitelikte olan, taze ya da olgunlaştırıldıktan sonra tüketilen, geleneksel olarak koyun veya keçi sütünden ya da her ikisinin karışımından üretilen, son zamanlarda sadece inek sütünden de yapılabilen bir peynir çeşididir (İnce ve ark., 1998; Kaminarides ve ark., 2000; Papademas ve ark., 1998; Robinson, 1991).
Hellim peyniri Kıbrıs'ta üretilen geleneksel bir peynirdir. Bu ürün çoğunlukla Kıbrıs, Türkiye, İngiltere, Lübnan gibi ülkelerde tüketilmesine rağmen, son yıllarda Avrupa Birliği ülkeleri, Amerika Birleşik Devletleri gibi ülkelerde de tüketilmeye başlanmıştır (Erbay ve ark., 2010).

Hellim peyniri, genellikle çiğ sütten starter kültür kullanılmadan üretilmekte ve telemesi belirli 
boyutta dilimlenerek haşlanmaktadır (Erbay ve ark., 2010). Geleneksel olarak hellim peynirinin üretiminde çiğ süt kullanılırken, günümüzde starter kültür ve pastörize sütten üretimi de yaygınlaşmaktadır. Geleneksel üretimde çiğ süte isteğe bağlı olarak peynirin renginde beyazlık sağlamak amacıyla klorofil katılabilmektedir. Sütün pıhtılaştırılma işlemi renet kullanılarak $33 \pm 1{ }^{\circ} \mathrm{C}^{\prime}$ de yapılmakta ve oluşan pıhtı yaklaşık $1 \mathrm{~cm}^{3 \prime}$ lük parçalar halinde kesilmektedir. Pıhtı yaklaşık 10 dakika dinlendirildikten pıhtı $40{ }^{\circ} \mathrm{C}$ 'de 15 dakika ısıtılmakta ve ısıtma işlemi takiben baskıya alınmaktadır. Baskı işleminden sonra teleme yaklaşık olarak $8 \times 10 \times 4 \quad \mathrm{~cm}$ boyutlarında kesilmektedir. Bu işlem sonrasında peynir suyunda 90-95 ${ }^{\circ} \mathrm{C}$ 'de yaklaşık 30-80 dakika pişirilmektedir. Uygulanan ısıl işlemin ardından peynirler süzülmekte ve tuzlama işleminden sonra kalıplara alınmaktadır. Geleneksel üretimin yanı sıra endüstriyel üretimde prosesinde ise taze peynir, kuru tuzlama yapılmadan, kontrollü bir ortamda soğumaya bırakılmakta ve soğuma işlemi sonunda pastörize edilmiş soğuk ve tuzlu peynir alt suyundan $100 \mathrm{~kg}$ ağırlıktaki taşıyıcılara aktarılmaktadır. Salamura içerisine alınan Hellim peynirleri, istenilen tuz miktarı elde edilinceye kadar yaklaşık 18 saat kadar tutulmaktadır (Ince ve ark., 1998; Papademas, 2006). Üretimi tamamlanmış Hellim peyniri, taze veya olgunlaşmış şekilde piyasaya sunulmakta, olgunlaştırma işlemi ise genellikle salamura içerisinde yapılmaktadır (Gün ve Şimşek, 2011).

Türk Standartları 12513 numaralı “Hellim Peyniri" standardına göre, rutubet miktarının taze peynirde en çok \%46, olgunlaştırılmış peynirde ise en çok \%37 olması, tuz oranının taze peynirlerde en çok \%3-5, olgunlaştırılmışlardan en çok \%6-10 olması ve laktik asit cinsinden titrasyon asitliğinin ise en çok \%3.5 olması gerektiği belirtilmiştir. Yağ içeriği bakımından ise, taze Hellim peynirinde en az $\% 43$, olgunlaştırılmış Hellim peynirinde ise en az \%40 olması gerektiği belirtilmiştir. Mikrobiyolojik olarak ise Hellim peynirinde koagülaz pozitif $S$. aureus sayısının 5 örneğin ikisinde en çok $10^{3}$, üçünde ise en çok $10^{2}$ adet olması, Salmonella spp. ve Listeria monocytogenes'in ise $25 \mathrm{gr}$ peynir örneğinde bulunmaması istenmiştir (TSE, 2018).

Yapılan literatür taramasında, son yıllarda Türkiye'de sıklıkla tüketilmeye başlanan Hellim peynirinin mikrobiyolojik ve kimyasal kalitesinin araştırıldığı çalışma sayısının oldukça sınırlı sayıda olduğu görülmüştür. Bu kapsamda bu çalışmanın amacı, Elazığ piyasasında satışa sunulan Hellim peynirlerinin kimyasal ve mikrobiyolojik analizlerinin yapılarak elde edilen verilerin literatürdeki mevcut eksikliğin giderilmesinde yardımcı olması amaçlanmıştır.

\section{Materyal ve Metot}

Bu çalışmada materyal olarak Elazığ ilinde satışa sunulan, farklı ticari firmalara ve farklı seri numaralarına ait orijinal ambalajlarında satılan 30 adet Hellim peyniri örneği kullanılmıştır. Toplanan örnekler ambalajları açılmadan laboratuvara getirilmiş ve analize alınıncaya kadar $4 \pm 1{ }^{\circ} C^{\prime}$ de muhafaza edilmiştir. Örnekler her ay en az 10 numune olacak şekilde toplanmış ve mevcut çalışma Ekim-Aralık 2018 tarihleri arasında gerçekleştirilmiştir. Tüm örneklerde mikrobiyolojik ve kimyasal analizler gerçekleştirilmiştir.

Mikrobiyolojik analizler için Hellim peyniri örnekleri aseptik şartlarda açılmış ve steril numune alma poşetlerine $25 \mathrm{gr}$ olacak şekilde tartım yapılmıştır. Daha sonra üzerine steril $225 \mathrm{ml} \% 0.1$ peptonlu su (Merck, Darmstadt, Germany) ilave edilmiş ve stomacherde (Bagmixer ${ }^{\circledR}$, Interscience, France) homojenize edilmiştir. Örneklerin $10^{-1}{ }^{\prime}$ lik (1/10) dilüsyonu hazırlanmıştır. Homojenizasyon işlemini takiben $10^{-6}$ ya kadar desimal (ondalık) dilüsyonları yapılmıştır. Örneklerin her dilüsyondan plaklara ekimleri yapılmış ve inkübasyon süresi sonunda değerlendirmeye alınmıştır (Harrigan, 1998).

Toplam aerobik mezofilik bakteri (TAMB) sayımında Plate Count Agar (PCA) (Merck, Darmstadt, Germany) kullanışmış ve petri kutuları $35 \pm 1^{\circ} \mathrm{C}^{\prime}$ de 48 saat inkübasyona alınmıştır. İnkübasyon süresi sonunda petri kutularında üreyen koloniler sayılmıştır (Maturin ve Peeler, 2001). Maya-küf sayımı için Dichloran Rose Bengal Chloramphenicol Agar (DRBC) (Biokar, Beauvais/France) kullanıldı. Plaklar $25 \pm 1^{\circ} \mathrm{C}^{\prime}$ de 5 gün inkübe edilmiş ve inkübasyon süresi sonunda petri kutularında oluşan koloniler sayılmıştır (ICMSF, 1982). Koliform bakterilerin sayımı için Violet Red Bile Agar (VRB) (Biokar, Beauvais/France) kullanışmış ve petriler $37 \pm 1^{\circ} \mathrm{C}^{\prime}$ de 24 saat inkübasyona bırakılmıştır. İnkübasyon süresi sonunda koyu kırmızı renkli spesifik özellikteki koloniler sayılmıştır (ISO 4832, 2006). Enterobacteriaceae sayımı için Violete Red Bile Glucose Agar (VRBG) (Biokar, Beauvais/France) kullanılmış ve plaklar $37 \pm 1^{\circ} \mathrm{C}^{\prime}$ de 24 saat inkübasyona süresi sonunda kırmızı koloniler sayılmıştır. Biyokimyasal doğrulama için plaklardan rastgele seçilen 5 adet koloniden oksidaz testi yapılmıştır (ISO 21528-2, 2004). StaphylococcusMicrococcus'ların sayımı için Mannitol Salt Agar (Biokar, Beauvais/France) kullanılmış ve petriler $37 \pm 1^{\circ} C^{\prime}$ de $36-48$ saat inkübasyona bırakılmıştır. İnkübasyon süresi sonunda sarı renkli koloniler sayılmıştır (Bannerman, 2007). LactobacillusLeuconostoc-Pediococcus sayımı için de Man, Rogosa and Sharpe Agar (Biokar, Beauvais/France) 
ve plaklar $30 \pm 1^{\circ} \mathrm{C}^{\prime}$ de 72 saat inkübasyondan sonra koloniler sayılmıştır (ISO 15214, 1998). Laktik streptokoklar sayımı için M17 Agar (Biokar, Beauvais/France) kullanılmış ve plaklar $30 \pm 1^{\circ} \mathrm{C}^{\prime}$ de 48-72 saat inkübe edildikten sonra oluşan koloniler sayılmıştır (Terzaghi ve Sandine, 1975). E. coli sayımı için Tryptone Bile X Glucuronide Agar (Merck, Darmstadt, Germany) kullanılmış ve plaklar $30^{\circ} \mathrm{C}^{\prime}$ de 4 saat ve sonra $44^{\circ} \mathrm{C}^{\prime}$ de 18 saat inkübe edildimiş ve inkübasyon süresi sonunda yeşil renkli koloniler sayılmıştır (ISO 16649-2, 2001). Anaerobik bakterilerin sayımında Brewer Anaerobik Agar (Merck, Darmstadt, Germany) kullanılmış ve plakların anaerobik koşullarda $35 \pm 1{ }^{\circ} C^{\prime}$ de 48 saat inkübasyonundan sonra oluşan koloniler değerlendirilmiştir (Brever, 1942). Koagülaz pozitif Stafilokok sayısının belirlenmesi için Egg yolk Tellurit (Oxoid SR54, United Kingdom) eklenen Baird Parker Agar (Oxoid CM0275, United Kingdom) kullanılmış ve plaklar $36 \pm 1^{\circ} \mathrm{C}^{\prime}$ de 30 saat inkübe edilmiştir. İnkübasyon süresi sonunda besi yerinde gelişen spesifik koloniler Brain Heart Infusion Broth (BHI, CM0225, Oxoid, United Kingdom) veya Tyriptic Soy Broth'a (Biokar, Beauvais/France) aktarılmış ve $37^{\circ} \mathrm{C}^{\prime}$ de 24 saat inkübe edilmiştir. Steril boş tüpler içerisine $0.1 \mathrm{~mL}$ Broth'larda üreme gösteren kültürlerden eklenmiş ve üzerlerine üretici firmanın talimatına göre hazırlanan Bactident Coagulase'dan (Merck, 1.13306-0001, EDTA ilaveli Liyofilize Tavşan Plazması) $0.3 \mathrm{~mL}$ ilave edilmiştir. Daha sonra tüpler $37^{\circ} \mathrm{C}$ 'de 4 saat inkübasyona alınmıştır. İnkübasyon süresi sonunda tüpler içerisinde jel ya da pıhtı oluşumu değerlendirilmiştir. Koagülaz test pozitif olan kolonilerin miktarı şüpheli kolonilerin sayısıyla çarpılıp, beşe bölünmüş ve koagülaz pozitif Stafilokok miktarı hesaplanmıştır (ISO 6888-1, 2015; Lancette ve Beneett, 2001).

Kimyasal analizler için Peynir örneklerinin toplam asitlik değerleri titrasyon asitliği $(T S, 591)$ ile, pH tayini dijital pH metre (Selecta - pH 2001) ve su aktivitesi (aw) değerleri su aktivitesi cihazı (TESTO-650) ile belirlenmiştir (Lang ve Sternberg, 1980). Peynir örneklerinin kuru madde gravimetrik metotla (TS, 591), tuz Mohr metodu (TS EN ISO 5943) ile ve yağ Van Gulik yöntemi (TS, 3433) ile yapıldı. Gripon ve ark. (1975) tarafından belirtilen yönteme göre hazırlanan peynir örneklerinin toplam azot ve suda çözünen azot mikro Kjeldahl yöntemi (IDF, 1993) ile belirlenmiş ve bu değerler 6,38 ile çarpılarak protein içerikleri hesaplanmıştır. Kül miktarları ise AOAC'nin (Association of Official Analytical Chemist) belirttiği metoda göre tayin edilmiştir (AOAC, 1984).

İstatistiksel analizler için elde edilen mikrobiyolojik veriler logaritmaya çevrilerek ortalama ve standart sapma değerleri belirlenmiştir. Kimyasal analizlerin sonuçlarında da ortalama ve standart sapma değerleri tespit edilmiştir. Bu çalışmada Hellim peyniri örneklerinden mikrobiyolojik analizler sonucunda elde edilen verilerin hem mikroorganizmalar ve mikroorganizma gruplarının birbirleri ile ilişkilerini hem de kimyasal verilerin kendi aralarında ve mikrobiyolojik verilerle olan ilişkilerini ortaya koymak amacıyla korelasyon analizi yapılmıştır. Korelasyon katsayılarının belirlenmesinde pearson korelasyon analizi yapılmıştır. İstatistiksel analizlerde SPSS paket programı kullanılmıştır (SPSS, 2012).

\section{Bulgular}

Incelenen 30 adet hellim peyniri örneklerine ait mikrobiyolojik analiz sonuçları Tablo 1 ve Tablo 2'de, kimyasal analiz sonuçları Tablo 3'de ve pearson korelasyon analiz sonuçları ise Tablo $4^{\prime}$ de gösterilmektedir.

Tablo 1. Hellim peynirlerinin mikrobiyolojik analiz sonuçları ( $\left.\log _{10} \mathrm{kob} / \mathrm{g}\right)$.

\begin{tabular}{llll}
\hline Mikroorganizma & En az & En çok & $\begin{array}{l}\text { Ortalama } \pm \\
\text { Std. Sapma }\end{array}$ \\
\hline TMAB & 2.90 & 8.78 & $6.39 \pm 1.88$ \\
Koliform & $<1.00$ & 2.73 & $2.29 \pm 0.73$ \\
Staph.-Micro. & $<1.00$ & 5.91 & $2.63 \pm 1.62$ \\
Maya-Küf & $<1.00$ & 4.58 & $3.16 \pm 1.14$ \\
Lac.-Leu.-Pedi. & 2.00 & 7.97 & $5.43 \pm 1.73$ \\
Lactic Streptococ & 2.90 & 8.26 & $6.04 \pm 1.63$ \\
Enterobacteriaceae & $<1.00$ & 3.80 & $2.65 \pm 0.90$ \\
Staph. aureus & $<1.00$ & 5.74 & $2.81 \pm 1.54$ \\
Anaerob & 1.48 & 6.26 & $3.45 \pm 1.26$ \\
E. coli & - & - & - \\
Koagulaz (+) Staph.aureus & - & - & - \\
\hline
\end{tabular}

Korelasyon analizi sonucu elde edilen kimyasal bulgular incelendiği zaman tuz miktarı ile yağ miktarı arasında istatistiki olarak önemli negatif bir korelason ( $r=-0.669)$ olduğu saptanmıştır $(P<0,01)$. Mikrobiyolojik veriler arasında ise Enterobacteriaceae grubu ile StaphylococcusMicrococcus arasında ise pozitif bir korelasyon olduğu $(r=0.424)$ ve bu korelasyon katsayısının istatistiki olarak önemli olduğu tespit edilmiştir $(\mathrm{P}<0.05)$. Benzer şekilde koliform grup mikroorganizmalar ile $S$. aureus arasında da pozitif bir korelasyon olduğu $(r=0.416)$ olduğu ve bu değerin istatistiki olarak önemli olduğu tespit edilmiştir $\quad(P<0.05)$. S. aureus ile anaerob mikroorganizmalar arasında da pozitif bir korelasyon olduğu $(r=0.520)$ ve bu korelasyonun istatistiki olarak önemli olduğu tespit edilmiştir $(P<0.01)$ 
Tablo 2. Hellim peyniri örneklerinde tespit edilen mikroorganizma sayılarının n sayıları ve \% dağılımları.

\begin{tabular}{|c|c|c|c|c|c|c|c|c|c|c|c|c|}
\hline \multirow[b]{3}{*}{ Mikroor. } & \multicolumn{12}{|c|}{$\log _{10} \mathrm{kob} / \mathrm{g}$} \\
\hline & \multicolumn{2}{|c|}{$<1.00$} & \multicolumn{2}{|c|}{$1.00-1.99$} & \multicolumn{2}{|c|}{ 2.00-3.99 } & \multicolumn{2}{|c|}{$4.00-5.99$} & \multicolumn{2}{|c|}{$6.00-7.99$} & \multicolumn{2}{|c|}{$>8.00$} \\
\hline & $n$ & $\%$ & $n$ & $\%$ & $n$ & $\%$ & $n$ & $\%$ & $n$ & $\%$ & $\mathrm{n}$ & $\%$ \\
\hline TMAB & - & - & - & - & 4 & 13.33 & 5 & 16.67 & 15 & 50 & 6 & 20 \\
\hline Koliform & 26 & 86.67 & - & - & 4 & 13.33 & - & - & - & - & . & - \\
\hline Staph.-Micro. & 4 & 13.33 & 3 & 10 & 18 & 60 & 5 & 16.67 & - & - & . & - \\
\hline Maya-Küf & 19 & 63.33 & 2 & 6.67 & 6 & 20 & 3 & 10 & - & - & - & - \\
\hline Lac.-Leu.-Pedio. & & - & - & - & 12 & 40 & 14 & 46.67 & 4 & 13.33 & - & - \\
\hline Lactic Streptococ & - & - & - & . & 4 & 13.33 & 7 & 23.33 & 18 & 60 & 1 & 3.33 \\
\hline Enterobac. & 22 & 73.33 & 2 & 6.67 & 6 & 20 & - & . & - & & . & - \\
\hline S.aureus & 6 & 20 & 2 & 6.67 & 18 & 60 & 4 & 13.33 & - & - & - & \\
\hline Anaerob & 2 & 6.67 & 3 & 10 & 16 & 53.33 & 7 & 23.33 & 2 & 6.67 & - & - \\
\hline E. coli & 30 & 100 & - & - & - & - & - & - & - & - & - & - \\
\hline Koa..(+) S.aureus & 30 & 100 & - & - & - & - & - & - & - & - & - & - \\
\hline
\end{tabular}

Tablo 3. Hellim peynirlerinin kimyasal analiz sonuçları.

\begin{tabular}{lccc}
\hline Analiz & En az & En çok & Ortalama \pm Std. Sapma \\
\hline Kuru madde (\%) & 37.21 & 54.88 & $48.77 \pm 5.25$ \\
Kül (Kütlece) (\%) & 2.72 & 5.72 & $4.84 \pm 0.78$ \\
Tuz (Kuru maddede) (\%) & 4.00 & 12.13 & $6.84 \pm 2.27$ \\
Yağ (Kuru maddede) (\%) & 33.34 & 49.06 & $41.58 \pm 5.36$ \\
Protein (\%) & 22.86 & 39.11 & $30.33 \pm 7.38$ \\
pH & 6.16 & 6.95 & $6.58 \pm 0.23$ \\
$\mathrm{a}_{\mathrm{w}}$ (su aktivite değeri) & 0.830 & 0.921 & $0.88 \pm 0.03$ \\
Asitlik (\% L.A. cinsinden) & 0.07 & 0.29 & $0.15 \pm 0.07$
\end{tabular}

Tablo 4. Hellim peynirine ait mikrobiyolojik ve kimyasal verilerin pearson korelasyon katsayıları.

\begin{tabular}{|c|c|c|c|c|c|c|c|c|c|c|c|c|c|c|c|c|}
\hline & Kül & Asitlik & Tuz & $\mathrm{pH}$ & aw & Yağ & $\begin{array}{l}\text { Protein } \\
\end{array}$ & TMAB & Lactoba. & Lac. Strep. & Enterobac. & Koliform & Staph-Micro. & S.aureus & Maya-küf & Anaerob \\
\hline K.M. & $0.402^{*}$ & -0.173 & -0.044 & 0.124 & $-0.468^{*}$ & -0.410 & 0.202 & 0.271 & 0.192 & 0.270 & 0.175 & 0.328 & 0.096 & 0.052 & -0.106 & 0.323 \\
\hline Kül & & $0.425 *$ & 0.276 & -0.225 & -0.118 & -0.301 & -0.653 & $0.378^{*}$ & -0.005 & 0.243 & 0.258 & -0.060 & 0.085 & -0.127 & 0.196 & -0.144 \\
\hline Asitlik & & & $0.436 *$ & 0.153 & 0.104 & -0.180 & -0.424 & 0.025 & -0.177 & -0.086 & -0.011 & -0.230 & 0.142 & -0.351 & 0.047 & -0.297 \\
\hline Tuz & & & & 0.042 & -0.366 & $-0.669 * *$ & -0.815 & -0.196 & 0.217 & 0.180 & 0.119 & -0.220 & 0.271 & -0.324 & 0.370 & -0.363 \\
\hline $\mathrm{pH}$ & & & & & 0.049 & 0.262 & -0.395 & -0.180 & -0.067 & -0.122 & -0.089 & 0.181 & -0.013 & 0.091 & -0.181 & -0.039 \\
\hline aw & & & & & & $0.517 *$ & 0.045 & -0.329 & -0.315 & -0.409 & -0.411 & -0.350 & -0.454 & 0.302 & -0.006 & -0.155 \\
\hline Yă̆ & & & & & & & -0.381 & -0.265 & -0.360 & -0.197 & -0.437 & -0.178 & -0.719 & 0.039 & 0.060 & -0.312 \\
\hline Protein & & & & & & & & 0.815 & 0.241 & -0.768 & -0.781 & 0.460 & 0.711 & 0.791 & 0.174 & 0.759 \\
\hline TMAB & & & & & & & & & 0.302 & $0.418^{*}$ & $0.413 *$ & 0.362 & 0.249 & 0.046 & 0.055 & $0.425 *$ \\
\hline Lactoba. & & & & & & & & & & $0.626 * * *$ & $0.439 *$ & 0.262 & 0.025 & 0.094 & 0.184 & 0.275 \\
\hline Lac. Strep. & & & & & & & & & & & 0.345 & 0.255 & 0.136 & 0.285 & 0.275 & 0.318 \\
\hline Enterobac. & & & & & & & & & & & & $0.645^{* * *}$ & $0.424^{*}$ & 0.237 & 0.053 & $0.465 *$ \\
\hline Koliform & & & & & & & & & & & & & $0.489^{* *}$ & $0.416 *$ & -0.048 & $0.740^{* * *}$ \\
\hline Staph-Micro. & & & & & & & & & & & & & & 0.302 & -0.267 & $0.390^{*}$ \\
\hline S.aureus & & & & & & & & & & & & & & & -0.282 & $0.520^{* *}$ \\
\hline Maya-küf & & & & & & & & & & & & & & & & -0.183 \\
\hline
\end{tabular}




\section{Tartışma ve Sonuç}

Toplam aerob mezofilik bakteri sayısı (TAMB) incelenen hellim peyniri örneklerinde en az 2.90, en çok 8.78 ve ortalama olarak $6.39 \pm 1.88 \log _{10} \mathrm{kob} / \mathrm{g}$ düzeyinde bulunmuştur (Tablo 1). Bu bakteri grubunun incelenen hellim peynirlerinin 21 (\%70) $10^{6} \log _{10} \mathrm{kob} / \mathrm{g}^{\prime} \mathrm{dan}, 6$ (\%20) ise $10^{8} \log _{10} \mathrm{kob} / \mathrm{g}^{\prime} \mathrm{dan}$ fazla olduğu görüldü. TAMB sayısının yüksek bulunması üretimde genellikle çiğ süt kullanılmış olmasından kaynaklandığı düşünülmektedir. Elde edilen bu değerlerin Usca ve Erol'un (1998) bulmuş oldukları sayıdan (4.51) yüksek ancak Demirci ve Arıcı (1989) ile Williams ve Syson'un (1984) bulmuş oldukları değerden (8.60) düşük seviyelerde olduğu tespit edilmiştir.

Hijyen indikatörü olarak kabul gören ve özellikle peynirlerde lezzet, yapı ve aroma bozukluklarına neden olan bakteri grubu koliform grubu bakterilerdir. Bu grup bakteriler ayrıca peynirlerin olgunlaşması sırasında teknolojik hatalara da neden olabilmektedirler. Peynirlerdeki sayıları uygulanan teknolojik işlemlere, yapılan peynirin türüne, peynirin taze veya olgunlaşmış olmasına bağlı olarak değişebilmektedir. Incelenen hellim peyniri örneklerinde en az $<1,00$, en çok 2.73 ve ortalama olarak ise $2.29 \pm 0.73 \quad \log _{10} \mathrm{kob} / \mathrm{g}$ seviyesinde bulundu (Tablo 1). Örneklerdeki mikrobiyolojik dağılıma bakıldığında incelenen 26 örnekte sayının tespit edilebilir seviyenin altında olduğu ve 4 (\%13.33) örnekte ise sayının 2.00-3.99 $\log _{10} \mathrm{kob} / \mathrm{g}$ düzeyinde olduğu görüldü (Tablo 2 ). Hellim peyniri 1998 yılında yayınlanan standardına göre (TSE, 1998) incelenen 5 adet örneğin en fazla $1^{\prime}$ inde koliform sayısının $10^{2} \mathrm{kob} / \mathrm{g}$ olması gerektiği belirtilirken, 2018 yılında değiştirilen aynı standartta mikrobiyolojik kriterler arasında koliform bakteri sayısıyla ilgili bir limit bulunmamaktadır. Buna göre analiz edilen 30 adet hellim peyniri örneğinin 4'ünde (\%13.33) adı geçen eski standarda uyum göstermediği ancak değiştirilen standarda göre uygun olduğu belirlenmiştir. İncelenen hellim peyniri örneklerinde tespit edilen koliform grubu bakterilerin düzeylerinin bu konuda çalışma yapan bazı araştırmacıların (Usca ve Demirci, 1998) buldukları seviyeden oldukça düşük seviyelerde (\%26 ve \%31.5) olduğu görüldü. Atasever ve ark. (1999) deneysel olarak yapmış oldukları hellim peynirlerinde muhafaza süresine bağlı olarak koliform grubu mikroorganizmaların sürekli olarak azalma gösterdiğini bildirmişlerdir.

Staphylococcus'lar insan ya da hayvansal kökenli olduklarından dolayı gıdalarda fazla sayılarda olmaları sanitasyonun ya da yetersiz ısıl işlemlerini göstermektedir. Micrococcus'lar ise insan ve hayvanların derilerinde ayrıca toprakta ve sularda da mevcut olmasıyla çoğu yerde bulunabilen ve gıdalarda bozulmaya yol açan önemli bakterilerdir (Banwart, 1989; Jay, 2000). Hellim peynirlerinde Staphylococcus-Micrococcus sayısı en az <.1.00, en çok 5.91 ve ortalama olarak ise $2.63 \pm 1.62 \log _{10} \mathrm{kob} / \mathrm{g}$ olarak saptanmıştır (Tablo 1 ). Tablo 2 incelendiğinde bu grup mikroorganizmaların 1.00-6.00 $\log _{10} \mathrm{kob} / \mathrm{g}$ arasında sayıldıkları, 4 (\% 13.33) örnekte sayının tespit edilebilir seviyenin altında olduğu ve 18 (\%60) örnekte ise sayının 2.00$3.99 \log _{10} \mathrm{kob} / \mathrm{g}$ arasında olduğu gözlemlenmiştir (Tablo 2).

Maya ve küfler genelde gıda maddelerinin raf ömrü, kalitesi ve lezzetine üzerine etkili olmaktadırlar. İncelenen hellim peyniri örneklerinde maya ve küfler en az $<1.00$, en çok 4.58 ve ortalama olarak ise $3.16 \pm 1.14 \log _{10} \mathrm{kob} / \mathrm{g}$ düzeyinde bulunmuştur (Tablo 1). Bu mikroorganizmaların genel dağılımına bakıldığı zaman ise 19 (\%63.33) örnekte sayının tespit edilebilir seviyenin altında olduğu, 2 tanesinde sayının 1.00-1.99 $\log _{10} \mathrm{kob} / \mathrm{g}$ arasında ve 9 (\%30) örnekte ise sayının 2.00-5.99 $\log _{10} \mathrm{kob} / \mathrm{g}$ arasında olduğu gözlemlenmiştir (Tablo 2). Koliform grup bakteri sayılarında olduğu gibi Hellim peynirine ait olan 1998 yılında yayınlanan standarda göre (TSE, 1998) incelenen 5 adet örneğin en fazla birisinde maya ve küf sayısının $10^{2} \mathrm{kob} / \mathrm{g}$ olması gerektiği bildirilmektedir. Ancak 2018 yılında revize edilen edilen aynı standartta maya-küf sayısıyla ilgili bir limit bulunmamaktadır. Elde edilen bu sonuçların bazı araştırmacıların (Atasever ve ark., 1999; Usca ve Erol, 1998) sonuçlarından oldukça düşük seviyelerde olduğu gözlemlendi. Bu durum muhtemelen peynir yapımında kullanılan sütlerin kalitesinden, peynirleri muhafaza şartlarından ve ambalaj materyallerinin kalitelerinden kaynaklanmış olabileceği düşünülmektedir. Ayrıca maya-küf sayısının yüksek çıkması ürünlerin hijyenik şartlarda yapılmadığının bir kanıtı olabilmektedir.

\section{Lactobacillus-Leuconostoc-Pediococcus}

$(L L P)^{\prime}$ lar ürünlerin kendine özgü lezzet, aroma ve raf ömürleri üzerine olumlu etkiler yapan ve laktik asit bakteri grubunda bulunan bir bakteri grubudur. Bu grup mikroorganizmaların sayıları sütten gelen laktik asit bakteri sayısına ve peynirin üretim aşamasında havadan karışan bu grup mikroorganizmalarla kontamine olma seviyesine bağlı olarak değişmektedir. Laktik asit bakterilerinin tüm peynir türlerinde yüksek sayıda olması arzu edilen bir durumdur. Aksi halde koliform grubu başta olmak üzere diğer istenmeyen bakteri gruplarının üremesi ve faaliyetleri önlenememektedir. Dolayısıyla peynirlerde kokuşma, lezzet ve aroma bozukluğu ve insan sağlığını tehdit edebilecek seviyede zararlı bakterilerin çoğalması kaçınılmaz olmaktadır (Kurt ve ark., 1991; Tekinşen ve Akar, 2017). Lactobacillus-Leuconostoc-Pediococcus'lar en az 
2.00 , en çok 7.97 ve ortalama olarak ise $5.43 \pm 1.73$ $\log _{10} \mathrm{kob} / \mathrm{g}$ olarak saptanmıştır (Tablo 1 ). Tablo 2 incelendiği zaman 18 (\%60) örnekte LLP sayısının 4.00-7.99 $\log _{10} \mathrm{kob} / \mathrm{g}$ arasında olduğu belirlenmiştir.

Laktik streptokok grubu bakteriler süt ürünleri üretiminde starter kültür amaçlı olarak kullanılan başka bir bakteri grubudur. Ürünlerin lezzet, yapı, aroma ve raf ömürleri üzerinde etkilidirler. Ilave edildikleri süt ürünlerinde genel mikrofloraya hakim olabilen bir bakteri grubudur. Hellim peynirlerinde en az 2.90, en çok 8.26 ve ortalama olarak ise $6.04 \pm 1.63 \log _{10} \mathrm{kob} / \mathrm{g}$ düzeyinde bulunmuştur (Tablo 1). Mikroorganizmaların genel dağılımlarına bakıldığında 25 (\%83.33) örnekte sayının 4.00-7.99 $\log _{10} \mathrm{kob} / \mathrm{g}$ arasında olduğu 1 (\%3.33) örnekte ise $>8.00 \log _{10} \mathrm{kob} / \mathrm{g}$ düzeyinde olduğu bulunmuştur (Tablo 2).

Enterobacteriaeceae ailesine ait bakteriler ürünlerin hijyenik kalitelerinin önemli bir göstergesi olarak kabul edilmektedir ve ürünlerin mikrobiyal kaliteleri hakkında fikir vermektedir. Analiz edilen hellim peyniri örneklerinde sayı en az $<1.00$, en çok 3.80 ve ortalama olarak ise $2.65 \pm 0.90 \log _{10} \mathrm{kob} / \mathrm{g}$ olarak belirlenmiştir (Tablo 1). Tablo 2 incelendiği zaman 22 (\%73.33) örnekte sayının <1.00 $\log _{10}$ kob/g'dan az olduğu, 2 (\%6.67) örnekte 1.00-1.99 $\log _{10} \mathrm{kob} / \mathrm{g}$ ve 6 (\%20) örnekte ise 2.00-3.99 $\log _{10}$ kob/g arasında olduğu saptanmıştır (Tablo 2). Hellim peyniri yapım teknolojisi gereği çiğ sütten ve starter kültür katılmadan yapılan ve telemesi ısıl işlem gören bir üründür. $\mathrm{Bu}$ nedenle hijyen indikatörü olarak da kabul gören bu bakteri grubunun ürünlerde üremesi muhtemelen Isıl işlemden sonraki aşamalarda kontaminasyon olduğunu düşündürmektedir. Çalışmada elde edilen bulguların Usca ve Erol'un (1998) hellim peynirlerinde tespit ettikleri seviyeden (\%52'sinde $3.00 \log _{10} \mathrm{kob} / \mathrm{g}^{\prime}$ dan fazla) oldukça düşük olduğu gözlemlendi.

Bazı Staphylococcus suşlarının gıda kaynaklı zehirlenmelerinde önemli rol oynadıkları bilinmektedir. Bu sebeple özellikle S. aureus'un gıdalarda bulunmaması gerekmektedir. Bu bakteriye en az $<1.00$, en çok 5.74 ve ortalama olarak ise $2.81 \pm 0.90 \quad \log _{10} \mathrm{kob} / \mathrm{g}$ olarak tespit edilmiştir (Tablo 1). Incelenen hellim örneklerinin 6 (\%20) tanesinde sayı tespit edilebilir seviyenin altında olduğu belirlenmiştir. Örneklerin 26 (\%80) tanesinde ise sayının 1.00-5.99 $\log _{10} \mathrm{kob} / \mathrm{g}$ arasında olduğu bulunmuştur (Tablo 2). Ancak tespit edilen $S$. aureus'un hiçbirinde koagülaz pozitif stafilokok suşuna rastlanılmadı. Hellim peyniri yapım teknolojisi gereği telemesi ısıl işlen gören bir peynir olmasına rağmen $S$. aureus'un bulunması muhtemelen Isıl işlemden sonra personel hijyen eksikliği, alet ve ekipmanların kullanımındaki hijyen eksikliği ve soğuk zincirde meydana gelebilecek aksaklıklardan kaynaklanmış olabileceği düşünülmektedir.

Analiz edilen hellim peyniri örneklerinde anaerob bakteri sayısı en az 1.48 , en çok 6.26 ve ortalama olarak ise $3.45 \pm 1.26 \quad \log _{10} \mathrm{kob} / \mathrm{g}$ seviyesinde tespit edilmiştir (Tablo 1). Bu mikroorganizmaların genel dağılımına bakıldığında ise incelenen 2 (\%6.67) örnekte sayının <1.0 $\log _{10}$ kob/g'dan az olduğu, 3 (\%10) örnekte 1.00-1.99 $\log _{10} \mathrm{kob} / \mathrm{g}$ arasında, 16 (\%53.33) örnekte 2.00-3.99 $\log _{10} \mathrm{kob} / \mathrm{g}$ arasında, 7 (\%23.33) $4.00-5.99 \log _{10}$ kob/g arasında ve 2 (\%6.67) örnekte ise 6.00-7.99 $\log _{10} \mathrm{kob} / \mathrm{g}$ arasında olduğu belirlenmiştir (Tablo 2). Hijyenik kalitenin bir göstergesi olan ve gıda zehirlenmelerine neden olan bakterilerden birisi de E. coli'dir. Analiz edilen hellim peynirlerinin tamamında (\%100) bu bakteriye rastlanılmadı (Tablo 1 ve Tablo 2). Elde edilen korelasyon bulguları, yapılan literatür taramasında daha önce bu konuda yapılan çalışmalarda böyle bir veriyle karşılaşılmadığı için tartışılamamıştır. Ancak bu çalışamda elde edilen korelasyon bulgular göstermektedir ki bazı mikroorganizma grupları (Enterobacteriaceae-Staphylococcus ve Micrococcus.; Anaerob-S. aureus; Koliform-Staph. aureus) arasındaki istatistiki olarak önemli korelasyon katsayıları Hellim peynirinin mikrobiyolojik kalitesinin belirlenmesinde önemli bir gösterge olarak kullanılabilme potansiyelini göstermektedir.

Kimyasal olarak hellim peynirleri incelendiği zaman kuru madde miktarı en az \%37.21, en çok \% 54.88 ve ortalama olarak $48.77 \pm 5.25$ saptandı (Tablo 3). Hellim peynirine ait olan standarda göre (TSE, 2018) kuru madde miktarı taze hellim peynirinde en az \%54 olgunlaştırılmış hellim peynirlerinde ise en az $\% 63$ olmalıdır. Buna göre analiz edilen olgunlaştırılmış 30 adet hellim peynirinin tamamının standarda uygunluk göstermediği belirlenmiştir. Tespit edilen kuru madde miktarının bazı araştırmacıların (Atasever ve ark., 1999; Demirci ve Arıcl, 1989) hellim peynirlerinde buldukları değerlerinden (\%58.89 ve \%60.21) daha düşük seviyelerde olduğu görülmüştür.

Gıda maddelerinde bulunan kül miktarı gıdaların kalitesini belirleyen parametrelerden birisidir. Incelenen hellim peynirlerine kül miktarı en az $\% 2.72$, en çok $\% 5.72$ ve ortalama olarak ise $\% 4.84 \pm 0.78$ olarak tespit edilmiştir (Tablo 3 ). Elde edilen bu değerlerin bazı araştırmacıların (Atasever ve ark., 1999; Demirci ve Arıcı, 1989) bulgularından (\%5.76 ve \%7.17) düşük seviyelerde olduğu saptandı.

Gıdalara ilave edilen tuz miktarı ürünlerin lezzetine, aromasına ve raf ömrünü etki etmektedir. Analize alınan hellim peynirlerinde tuz miktarı (kuru 
maddede) en az $\% 4.00$, en çok $\% 12.13$ ve ortalama değer olarak da \%6.84 \pm 2.27 tespit edilmiştir (Tablo 3). Hellim peyniri standardına göre tuz miktarı (kuru maddede) taze hellim peynirinde en çok \%5 olgunlaştırılmış hellim peynirinde ise en çok $\% 10$ olmalıdır. Buna göre analiz edilen 30 adet olgunlaştırılmış hellim peyniri örneğinin sadece 1 (\%3.33) tanesinin standartlara uygunluk göstermediği belirlendi. Tespit edilen bu değerlerin bazı araştırmacıların (Atasever ve ark., 1999; Demirci ve Arıcı, 1989) bulgularından (\%5.09 ve \%6.14) çok düşük değerlerde olduğu görüldü.

Gıda maddelerinde bulunan yă̆ miktarı ürünlere lezzet ve aroma vermektedir. Aynı zamanda ürünlerin kalitesini de belirlemede yardımcı olmaktadır. Incelenen hellim peynirlerinde yağ miktarı (kuru maddede) en az \%33.34, en çok $\% 49.06$ ve ortalama olarak ise \%41.58 \pm 5.36 değerinde bulunmuştur (Tablo 3). Türk Patent Enstitüsü'nün (TPE, 2008) vermiş olduğu Coğrafi İşaret belgesine göre; kuru madde de yağ miktarı en az \%43 olduğu bildirilmiştir. Buna göre analiz edilen hellim peynirlerinin sadece 6 tanesinde yağ miktarının belirtilen normlara uygunluk gösterdiği belirlendi. Protein miktarı en az \%22.86, en çok $\% 39.11$ ve ortalama olarak ise $\% 30.33 \pm 7.38$ düzeyinde olduğu gözlemlenmiştir (Tablo 3 ).

$\mathrm{pH}$ değeri mikroorganizmaların üremeleri ve gıdaların raf ömürleri üzerinde etkili olan önemli kriterlerden biridir. pH değeri en az 6.16, en çok 6.95 ve ortalama olarak ise $6.58 \pm 0.23$ olarak belirlenmiştir (Tablo 3). Hellim peyniri standardına göre (TSE, 2018); pH değeri en çok 6.6 olmalıdır. Buna göre analiz edilen hellim peynirlerinin $\mathrm{pH}$ değerlerinin yarısının (\%50) bu değerlere uymadığı ve standartların üstünde değerlere sahip oldukları görüldü. Su aktivite değeri (aw) mikroorganizmaların gelişmeleri için gerekli olan ve gıdaların kalitelerinin korunmasında etkili olan önemli bariyerlerden biridir. En az 0.830 ve en çok 0.921 ortalama olarak ise $0.88 \pm 0.03$ seviyesinde saptandı (Tablo 3 ).

Asitlik değeri, ürünlerin kimyasal olarak dayanıklılığını, standartlara uygun olup olmadığını ve kimyasal kalitesinin belirlenmesinde önemli parametrelerden birisidir. En az \%0.07 l.a (laktik asit), en çok \%0.29 l.a ve ortalama olarak ise $0.15 \pm 0.07$ l.a olarak bulundu (Tablo 3). Hellim peyniri standardına göre laktik asit cinsinden en çok \%3.5 olmalıdır. Buna göre incelenen örneklerin tamamının (\%100) standartlarla uyum içerisinde olduğu görüldü. Elde edilen bu değerlerin Atasever ve ark. (1999) tarafından saptamış oldukları \%0.53 asitlik değerinden oldukça düşük seviyelerde olduğu belirlendi.

Sonuç olarak, hellim peynirlerinin mikrobiyolojik kalitesinin iyileştirilmesi ve halk sağlığı bakımından kaliteli ürünlerin elde edilmesi için üretimden tüketime kadar olan tüm aşamalarında kritik kontrol noktalarına gereken önem verilmeli, kontaminasyon riski azaltılmalı ve tüm üretim aşamalarında gerekli hijyenik önlemler alınmalıdır.

\section{Kaynaklar}

Association of Official Analytical Chemists, 1984: Official Methods of Analysis. 14th ed., Association of Analytical Chemists, Washington, DC.

Atasever M, Keleş A, Uçar G, Güner A, 1999: Farklı ambalajlarda muhafaza edilen hellim peynirinin olgunlaşması süresince bazı kalite niteliklerindeki değişimler. Vet Bil Derg, 15, 1, 55-64.

Bannerman, T. L, 2007: Staphylococcus, Micrococcus and other catalase-positive cocci. Manual of clinical microbiology, 390-411.

Banwart GJ, 1989: Basic Food Microbiology, 1. Food Microbiology. 2nd Edition New York, Avi Book Published by Van Nostrand Reinhoid.

Brewer, J.H, 1942: A new Petridish and technique for use in the cultivation of anaerobes and microaerophiles. Science, 95; 587

Demirci M, Arıcı M, 1989: Hellim peynirinin fiziksel, kimyasal ve mikrobiyolojik özellikleri üzerinde araştırmalar. Bursa I. Uluslararası Gıda Sempozyumu, Bursa.

Erbay Z, Koca N, Üçüncü M, 2010: Hellim peynirinin bileşimi ile renk ve dokusal özellikleri arasındaki ilişkiler. Gıda, 35 (5): 347-353.

Gripon J.C, Desmazeaud M.J, Bars J.L, Bergere J.L. 1975: Rolle des microorganismes et des enzymes du cours de la maturation. Le Lait 55: 502-516.

Gün I, Şimşek B, 2011: Türkiye'de ve Kuzey Kıbrıs Türk Cumhuriyeti'nde üretilen hellim peynirlerinin bazı Özelliklerinin karşılaştırılması. Harran Üniversitesi Ziraat Fakültesi. Dergisi, 15(1): 43-53.

Harrigan WF, 1998: Laboratory methods in food microbiology. 3rd ed., Academic Press, London.

IBM SPSS, IBM Corp. Released 2012: IBM SPSS Statistics for Windows, Version 21.0. Armonk, NY: USA

International Commission on Microbiological Specifications for Foods (ICMSF), 1982: Microorganism in Foods 1. Their Significance and Methods of Enumeration, London, Univto Toronto Press.

International Dairy Federation (IDF), 1993: Milk Determination of Nitrogen Content. IDF Standard 20B. Brussels, Belgium.

International Organization for Standardization (ISO) 15214, 1998: Microbiology of food and animal feeding stuffs -Horizontal method for the enumeration of mesophilic lactic acid bacteria Colony-count technique at 30 degrees C. 21.

International Organization for Standardization (ISO) 16649-2, 2001: Microbiology of food and animal feding stuffs-Horizontal method for the detection and enumeration of $\beta$-glucuronidase-positive Escherichia coli. Part 2, Colony-count technique a $44^{\circ} \mathrm{C} \quad$ using 5-brome-4chloro-3-indoly-betaDglucuronide, Geneve, Switzerland. 
International Organization for Standardization (ISO) 21528-2, 2004: Microbiology of food and animal feding stuffs-Horizontal methods for the detection and enumeration of Enterobacteriaceae-Part 2: Colony-count method.

International Organization for Standardization (ISO) 4832, 2006: Microbiology of food and animal feding stuffs-Horizontal method for the enumeration on coliforms-Colony-count technique.

International Organization for Standardization (ISO/CD) 6888-1, 2015: Microbiology of food and animal feeding stuffs-Horizontal method for the enumeration of coagulase-positive staphylococci (Staphylococcus aureus and other species) - Part 1: Technique using Baird-Parker agar medium.

Ince H, Çıldam, T, Özbağ, M, 1998: Hellim peyniri. $V$. Süt ve Süt Ürünleri Sempozyumu Geleneksel Süt Ürünleri, 89-95.

Jay MJ, 2000: Modern Food Microbiology. 6th ed., Aspen Publishers, Inc., Gaithersburg, Maryland, USA.

Kaminarides S, Rogoti E, Mallatou H, 2000: Comparison of the characteristics of halloumi cheese made from ovine milk, caprine milk or mixtures of these milks. Int J Dairy Technol, 53(3), 100-105.

Kurt A, Çağlar A, Çakmakçı S, 1991: Erzincan (Şavak) tulum peynirinin mikrobiyolojik özellikleri üzerinde bir araştırma. Doğa Tr J of Vet and Anim Sci, 16, 41-50.

Lancette GA, Bennett RW, 2001: Staphylococcus aureus and staphylococcal enterotoxins. In "Microbiological Examination of Foods", Ed; Downes FP, 387-404, American Public Health Association, Washington DC.

Lang KW, Sternberg MP, 1980: Calculation of moisture content of a formulated food system to any shown water activity. Journal of Food Science, 45: 12281230.

Maturin LJ, Peeler JT, 2001: Bacteriological Analytical Manual. chapter 3. United States Food and Drug Administration (US FDA); Aerobic plate count. http://www.fda.gov/ Food/ Food Science Research/Laboratory Methods/ucm063346.htm. Erişim tarihi; 15.03.2019.
Papademas P, Robinson R. K, 1998: Halloumi cheese: the product and its characteristics. International Journal of Dairy Technology, 51(3), 98-103.

Papademas P, 2006: Halloumi Cheese In: Brined Cheeses. Tamime A. Ed., Blackwell Publishing, S 117-138.

Robinson RK, 1991: Halloumi cheese-the productand its manufacture. In "Feta and Related Cheese, Ed., RK Robinson, A.Y. Tamime, 144-159. Ellis Horwood, London.

Tekinşen KK, Akar D, 2017: Erzincan tulum peyniri. Ata Üniv Vet Bil Derg, 12 (2), 218-226.

Terzaghi BE, Sandine WE, 1975: Improve medium for lactic streptococci and their bacteriophages. Appl Microbiol, 29, 807-813.

Türk Patent Enstitüsü (TPE), 2008: Hellim Peyniri. C2008/046, Türk Patent Enstitüsü Coğrafi İşaret Tescil Belgesi, Ankara.

Türk Standartları Enstitüsü (TSE), 1998: Türk Standartları Enstitüsü, Hellim Peyniri, TS: 12513, Ankara.

Türk Standartları Enstitüsü (TSE), 2013: Beyaz Peyniri Standardı, TS. 591. Ankara.

Türk Standartları Enstitüsü (TSE), 2015: Peynir, Yağ muhtevası Taynini, Van Gulik Metodu TS.3433. Ankara.

Türk Standartları Enstitüsü (TSE), 2018: Türk Standartları Enstitüsü, Hellim Peyniri, TS: 12513 Ankara.

Türk Standartları Enstitüsü, TS EN ISO 5943, 2007: Peynir ve eritme peynir ürünleri- Klorür miktarı tayiniPotansiyometrik titrasyon metodu

Usca A, Erol i, 1998: Hellim peynirinin mikrobiyolojik kalitesi. Ankara Üniv Vet Fak Derg, 45, 97-103.

Williams MR, Syson R, 1984: The bacteriological quality of Cyprus cheese. Environ Health, 92, 146-149.

*Yazışma Adresi: Mehmet Emin AYDEMiR

Harran Üniversitesi, Veteriner Fakültesi, Besin Hijyeni ve Teknolojisi Bölümü, 63200 Şanlıurfa, Türkiye

E-mail: aydemiremin23@gmail.com 